\title{
PERAN WANITA DALAM PERUBAHAN SOSIAL MELALUI KEPEMIMPINAN POSDAYA
}

\author{
Nalis Siti Khaerani \\ Universitas Pendidikan Indonesia \\ Jl. Dr.Setiabudi 229 Bandung 40154, Jawa Barat, Indonesia \\ Email: nalis.siti.khaerani@student.upi.edu
}

\begin{abstract}
Abstrak Penelitian ini dilatarbelakangi karena konstruksi masyarakat yang masih meragukan kepemimpinan wanita. Penelitian ini bertujuan untuk memaparkan: Kondisi sosial-ekonomi masyarakat setelah dibentuknya Posdaya yang dipimpin oleh wanita. Penelitian ini menggunakan metode kualitatif dengan metode deskriptif. Teknik pengumpulan data dilakukan dengan teknik wawancara mendalam, observasi partisipasi, studi literatur, dan studi dokumentasi. Informan peneliti terdiri dari pemimpin, pengurus, anggota Posdaya, dan masyarakat yang berada disekitar Posdaya. Hasil penelitian menunjukan: Kondisi sosial-ekonomi masyarakat mengalami perubahan. Keswadayaan dan kemandirian sebagai semangat kerjanya berhasil menciptakan perubahan sosial yang mengarah pada tujuan pembangunan abad millennium atau MDGs.

Kata kunci: kepemimpinan wanita, perubahan sosial, posdaya
\end{abstract}

\section{PENDAHULUAN}

Secara biologis perbedaan wanita dengan pria bersifat kodrat, artinya memang pada dasarnya terdapat perbedaan dan batasan-batasan antara pria dan wanita sehingga menimbulkan konstruksi masyarakat dan stereotipe gender. Terkadang stereotipe gender yang dibangun oleh masyarakat menyudutkan salah satu pihak khususnya terhadap kaum wanita.

Dalam menjalankan peranannya, kaum wanita dihadapkan pada peranan ganda, yakni peranan domestik dan peranan publik. Seiring perkembangan zaman, peran wanita dalam segala aspek sangat dibutuhkan seperti pada bidang pendidikan, kesehatan, sosial-politik, ekonomi, hukum, dan lainlain. Peranan domestik wanita adalah peranan sosial yang terkait dengan aktivitas internal rumah tangga, seperti memasak, mengurus anak, dan melayani suami. Sedangkan peranan publik, dapat diartikan sebagai keikutsertaannya dalam berbagai aktivitas di bidang ekonomi, pendidikan, kesehatan, dan sosialpolitik, dalam rangka keterlibatannya untuk menciptakan suatu perubahan di lingkungan masyarakat.

Perubahan dalam lingkungan masyarakat akan terwujud ketika sekumpulan individu yang ada di dalam lingkungan tersebut memiliki perasaan tidak puas terhadap keadaan yang ada di lingkungannya sehingga, mereka memiliki keinginan untuk melakukan suatu perubahan.
Selain itu, satu hal yang tidak kalah penting untuk mewujudkan perubahan dalam masyarakat yakni, keberadaan seorang pemimpin yang dianggap mampu menampung keinginan masyarakat atas rasa ketidakpuasannya. Ketidakpuasan yang dirasakan oleh masyarakat harus dihilangkan oleh seorang pemimpin melalui tujuan yang telah direncanakan baik yang sifatnya konkret dan dapat dilihat oleh masyarakat maupun tujuan abstrak seperti ideologi tertentu.

Untuk menumbuhkan rasa kepedulian dan partisipasi masyarakat terhadap permasalahan dan ketidakpuasan yang ada di lingkunganya dalam rangka mewujudkan perubahan, dapat disiasati melalui peran kepemimpinan seseorang yang bisa memberikan stimulus positif terhadap masyarakat. Menurut Farland (dalam Denim, 2012, hlm. 55) menyatakan bahwa "Kepemimpinan adalah suatu proses dimana pimpinan dilukiskan akan memberikan perintah atau pengaruh, bimbingan atau proses mempengaruhi pekerjaan orang lain dalam memiliki dan mencapai tujuan yang telah ditetapkan".

Dewasa ini untuk mewujudkan tujuan perubahan yang telah direncanakan, pemerintah bekerja sama dengan berbagai pihak kelembagaan untuk membentuk suatu wadah pemberdayaan agar dapat mendorong masyarakat kearah perubahan yang lebih baik.

Posdaya (Pos Pemberdayaan Keluarga) merupakan suatu wadah pemberdayaan bagi 
keluarga yang berada pada kondisi sosial-ekonomi lemah serta sebagai forum silaturahmi bagi masyarakat untuk bergabung dalam suatu proses pemberdayaan bersama. Untuk itu, dalam pelaksanaan kegiatan Posdaya diperlukan pemimpin yang memiliki kemampuan serta loyalitas untuk dapat mempengaruhi serta mengajak masyarakat agar ikut serta dalam pencapaian suatu tujuan perubahan.

Salah satu contoh keberhasilan perubahan sosial terkait kemajuan pada bidang pendidikan, kesehatan dan ekonomi sebagai implikasi dari pembentukan Posdaya adalah keberadaan Pos Pemberdayaan Keluarga (Posdaya) Plamboyan warga Kampung Sukamaju Timur RW 11 Desa Kayuambon Lembang Jawa Barat.

Karena keberhasilannya, Posdaya Plamboyan kini menjadi Posdaya rujukan nasional dan menjadi perhatian bukan saja kehidupan gotong royongnya namun, yang membanggakan adalah aktivitas usaha anggotanya yang semakin bervariasi untuk mewujudkan perubahan yang bersifat konstruktif dalam lingkungan masyarakatnya. Kegiatan variatif yang dilakukan oleh Posdaya Plamboyan ini, merupakan kegiatan yang mendukung tercapainya pembangunan abad millennium yaitu sasaran dan target MDGs.

Melalui serangkaian kegiatan produktif yang dilakukan Posdaya Plamboyan, menghantarkan masyarakat Kampung Sukamaju Timur RW 11 Desa Kayuambon menuju arah perubahan yang mengarah pada tujuan MDGs dan berhasil meraih penghargaan juara I sebagai Posdaya Terbaik Rujukan Nasional pada 15 Januari 2016 di acara HUT Yayasan Damandiri ke-20. Keberhasilan Posdaya Plamboyan sendiri tidak bisa dipungkiri merupakan sebuah hasil dari kerja keras dan usaha

Suatu hal yang kontradiktif sebenarnya, jika mengingat keberhasilan Posdaya Plamboyan dilatarbelakangi oleh pemimpin wanita. Dibalik konstruksi masyarakat yang menilai wanita sebagai makhluk lemah, peran kepemimpinan wanita pada Posdaya Plamboyan yang ada di Kampung Sukamaju Timur RW 11 Desa Kayuambon ini mampu membuktikan bahwa untuk mewujudkan suatu kemajuan dalam bentuk perubahan dibutuhkan pemimpin yang tangguh, bertanggung jawab, memiliki integritas dan loyalitas yang tinggi.

Peran kepemimpinan wanita dalam mewujudkan perubahan sosial terkait dengan kemajuan di bidang pendidikan, kesehatan dan ekonomi melalui kegiatan Pos Pemberdayaan Keluarga (Posdaya) merupakan hal yang menarik sebagai bentuk usaha dalam menciptakan partisipasi masyarakat untuk meminimalisir rasa ketidakpuasan atas keadaan yang ada di lingkungannya.

Oleh karena itu, perlu dilakukan pengkajian secara serius sebagai referensi atau rujukan bagi Posdaya lain yang ingin ikut serta berpartisipasi dalam upaya mewujudkan tujuan perubahan yang bersifat konstruktif dalam rangka peningkatan mutu kehidupan masyarakat.

\section{METODE PENELITIAN}

Pada penelitian ini, peneliti menggunakan metode penelitian kualitatif. Dipilihnya metode penelitian kualitatif ini didasarkan pada permasalahan yang dikaji mengenai studi deskriptif peran wanita dalam perubahan sosial melalui kepemimpinan Posdaya, tidak dapat diukur dengan menggunakan hitungan dan hipotesis.

Partisipan dalam penelitian ini adalah orangorang yang berkaitan dengan Posdaya Plamboyan, yaitu masyarakat sekitar Kampung Sukamaju Timur RW 11 Desa Kayuambon sebagai anggota Posdaya Plamboyan, pengurus inti Posdaya Plamboyan, serta Pemimpin Posdaya Plamboyan yang dalam hal ini akan memberikan informasi mengenai peran kepemimpinannya dalam perubahan sosial melalui kegiatan pemberdayaan keluarga.

Penelitian ini tidak melibatkan seluruh populasi yang ada untuk menjadi partisipan dalam penelitian, artinya partisipan yang dimintai informasi oleh peneliti adalah mereka yang telah melalui pertimbangan tertentu misalnya, orang yang dianggap paling tahu tentang informasi yang dicari. Maka atas dasar pertimbangan itu, pada penelitian ini peneliti menggunakan purposive sampling sebagai teknik pengambilan sampel.

Penelitian ini menginginkan gambaran yang mendalam mengenai peran wanita dalam perubahan sosial sebagai implikasi dari kepmimpinan Posdaya Plamboyan di Kampung Sukamaju Timur RW 11 Desa Kayuambon, Lembang, Jawa Barat. Perolehan data serta informasi dalam penelitian ini menggunakan beberapa teknik antara lain, observasi partisipatif, wawancara mendalam, studi dokumentasi serta studi litelatur.

\section{HASIL DAN PEMBAHASAN}

Eksistensi keberhasilan pemimpin wanita dalam menjalankan peranan ganda kini menjadi modal untuk membuktikan kemampuannya dalam memimpin dan mengorganisir suatu lembaga atau 
kelompok dimasyarakat. Kesuksesan yang ditorehkan oleh pemimpin Posdaya Plamboyan yang berlatarbelakang seorang wanita semakin membuktikan bahwa kepemimpinan tidak ada kaitannya dengan jenis kelamin.

Menurut Ahdiah (2013, hlm. 1087) menyatakan bahwa "Analisa peran perempuan dapat dilakukan dari perspektif posisi mereka dalam berurusan dengan pekerjaan produktif tidak langsung (domestik) dan pekerjaan produktif langsung (publik)." Analisa tersebut dapat dilihat sebagai berikut :

1. Peran Tradisi menempatkan perempuan dalam fungsi reproduksi mengurus rumah tangga, melahirkan dan mengasuh anak, serta mengayomi suami. Hidupnya $100 \%$ untuk keluarga. Pembagian kerja sangat jelas, yaitu perempuan di rumah dan lelaki di luar rumah.

2. Peran transisi mempolakan peran tradisi lebih utama dari peran yang lain. Pembagian tugas mengikuti aspirasi gender, tetapi eksistensi mempertahankan keharmonisan dan urusan rumah tangga tetap tanggung jawab perempuan.

3. Dwiperan memposisikan perempuan dalam kehidupan dua dunia, yaitu menempatkan peran domestik dan publik dalam posisi sama penting. Dukungan moral suami pemicu ketegaran atau sebaliknya keengganan suami akan memicu keresahan atau bahkan menimbulkan konflik terbuka atau terpendam.

4. Peran egalitarian menyita waktu dan perhatian perempuan untuk kegiatan di luar. Dukungan moral dan tingkat kepedulian lelaki sangat hakiki untuk menghindari konflik kepentingan pemilahan dan pendistribusian peranan. Jika tidak, yang terjadi adalah masing-masing akan saling berargumentasi untuk mencari pembenaran atau menumbuhkan ketidaknyamanan suasana kehidupan berkeluarga.

5. Peran kontemporer adalah dampak pilihan perempuan untuk mandiri dalam kesendirian. Jumlahnya belum banyak. Akan tetapi benturan demi benturan dari dominasi lelaki atas perempuan yang belum terlalu peduli pada kepentingan perempuan mungkin akan meningkatkan populasinya.

Peran wanita dalam penelitian ini berada pada analisa dwiperan dimana pemimpin Posdaya Plamboyan yang berlatarbelakang wanita menempatkan peranan domestik dengan peranan publik berada pada posisi sama penting. Dalam melakukan aktivitas kepemimpinannya, pemimpin Posdaya Plamboyan cenderung lebih bergaya transformasional dimana pemimpin tersebut lebih demokratis dan partisipatif.

Menurut Bintarto (dalam Febrina dkk, 2016, hlm. 44) mengemukakan bahwa "Kondisi sosial- ekonomi masyarakat adalah suatu usaha bersama dalam suatu masyarakat untuk menanggulangi atau mengurangi kesulitan hidup, dengan lima parameter dapat digunakan untuk mengukur kondisi sosial ekonomi masyarakat yaitu, tingkat pendidikan, pekerjaan, kesehatan, dan tingkat pendapatan”.

Dalam upaya untuk menanggulangi kesulitan hidup masyarakat, melakukan sebuah perubahan yakni melalui pendirian Posdaya Plamboyan. Keberadaan Posdaya Plamboyan memberikan implikasi yang sangat berpengaruh terhadap peningkatan kesejahteraan masyarakat, melalui program pemberdayaannya yang meliputi bidang pendidikan, ekonomi, kesehatan, lingkungan dan keagamaan.

Kondisi sosial-ekonomi masyarakat Kampung Sukamaju Timur RW 11 Desa Kayuambon Lembang Jawa Barat mengalami perubahan kearah yang lebih baik setelah didirikannya Posdaya Plamboyan, dengan kata lain keberadaan Posdaya Plamboyan yang dilatarbelakangi oleh pemimpin wanita memiliki andil yang sangat besar bagi terciptanya kesejahteraan masyarakat. Melalui kemampuannya dalam menggerakan dan memberdayakan masyarakat, kegiatan serta program Posdaya Plamboyan mendapatkan apresiasi yang tinggi sehingga hal itu sangat menguntungkan bagi terselenggaranya setiap program pemberdayaan yang telah direncanakan sebelumnya.

Dengan demikian dapat disimpulkan bahwa, kondisi sosial-ekonomi masyarakat Kampung Sukamaju Timur RW 11 Desa Kayuambon Lembang Jawa Barat mengalami perubahan kearah yang lebih baik setelah didirikannya Posdaya Plamboyan, dengan kata lain keberadaan Posdaya Plamboyan yang dilatarbelakangi oleh pemimpin wanita memiliki andil yang sangat besar bagi terciptanya kesejahteraan masyarakat.

Tinjauan Hasil Penelitian Terhadap Teori Struktural-Fungsional

Prinsip-prinsip pemikiran Talcott Parsons mengenai fungsionalisme-struktural secara umum bersifat general theory, artinya bahwa tindakan individu manusia itu diarahkan pada tujuan. Secara normatif tindakan tersebut diatur berkenaan dengan penentuan alat dan tujuan. Hal ini berarti bahwa tindakan itu dipandang sebagai kenyataan sosial yang terkecil dan mendasar, terdiri dari alat, tujuan, situasi, dan norma sebagai unsur-unsurnya.

Dilihat dari prosesnya, pencapaian tujuan program Posdaya Plamboyan yang dipimpin oleh seorang wanita di Kampung Sukamaju Timur RW 11 Desa Kayuambon sejalan dengan pendapat teori struktural-fungsional yang menyatakan lembaga sebagai suatu sistem yang ada dimasyarakat akan menjalankan empat fungsi sesuai dengan empat 
konsep yang diungkapkan oleh Parsons dengan istilah AGIL (Adaptation, Goal, Attainment, Integration and Latency).

Adaptasi (Adaptation) dalam Posdaya Plamboyan dilakukan dengan cara menciptakan kegiatan produktif bagi masyarakat. Kegiatan produktif tersebut disesuaikan dengan kebutuhan yang diperlukan masyarakat meliputi bidang pendidikan, ekonomi, kesehatan, dan lingkungan. Melalui kegiatan produktif tersebut pola pikir masyarakat diubah sesuai dengan tujuan dari pembentukan Posdaya Plamboyan. Dengan adanya kegiatan produktif yang diciptakan oleh Posdaya Plamboyan, masyarakat ikut pula mendukung dalam proses kegiatan sesuai dengan target sasaran pemberdayaan Posdaya Plamboyan.

Pencapaian tujuan (Goal) dilakukan oleh pemimpin Posdaya Plamboyan degan cara menjalin mitra kerjasama dengan beberapa lembaga seperti LPPM UPI, yayasan DAMANDIRI, BPK Syariah HIK Parahyangan, HIMAPAUDI Bandung Barat, dan Puskesmas Bandung Barat. Hasilnya, masyarakat yang tergabung dalam keanggotaan Posdaya Plamboyan dapat memberikan partisipasinya berupa ide/gagasan, materi serta tenaga dalam rangka pencapaian tujuan Posdaya Plamboyan yakni mencipatakan perubahan dan mewujudkan kesejahteraan.

Integrasi (Integration) dilakukan oleh pemimpin Posdaya Plamboyan dengan cara menanamkan nilai gotong royong pada masyarakat serta pengurus sebagai modal pencapaian target pemberdayaan masyarakat. Lembaga-lembaga yang menjadi mitra kerjasama Posdaya Plamboyan mengarahkan masyarakat agar turut serta dalam seluruh program kegiatan Posdaya Plamboyan. Modal gotong royong tersebut berhasil menghantarkan Posdaya Plamboyan meraih beberapa penghargaan salah satunya yakni sebagai Posdaya rujukan tingkat nasional. Prestasi tersebut membuktikan bahwa, partisipasi yang diberikan oleh masyarakat kepada Posdaya Plamboyan merupakan sebuah keberhasilan pemimpin Posdaya Plamboyan dalam menanamkan nilai gotong royong pada masyarakat serta pengurus Posdaya agar terciptanya suatu nilai kebersamaan atau integritas yang dibuktikan dengan berbagai bentuk partisipasi yang diberkan masyarakat kepada setiap program pemberdayaan di Posdaya Plamboyan.

Pemeliharaan (Latency) dilakukan oleh pemimpin Posdaya Plamboyan melalui penguatan fungsi keluarga. Keluarga dijadikan sebagai ujung tombak untuk memperbaiki pendidikan, ekonomi, dan kesehatan masyarakat dengan pilar keswadayaan dan kemandirian sebagai semangat kerjanya. Posdaya mewadahi kegiatan dari masyarakat, oleh masyarakat dan untuk masyarakat.
Berdasarkan pada uraian pembahasan hasil penelitian yang dikaitkan dengan berbagai teori, maka kepemimpinan yang dilakukan oleh seorang wanita pada Posdaya Plamboyan terbukti dapat mengarahkan masyarakat Kampung Sukamaju Timur RW 11 Desa Kayuambon Lembang Jawa Barat menuju perubahan yang bersifat konstruktif Dengan beragam upaya penyesuaian atau adaptasi yang dilakukan, pola perilaku masyarakat dapat berubah sesuai dengan tujuan pemberdayaan yang ada di Posdaya Plamboyan. Keluarga yang dijadikan ujung tombak sasaran pemberdayaan untuk memperbaiki pendidikan, ekonomi, dan kesehatan masyarakat dengan pilar keswadayaan dan kemandirian sebagai semangat kerjanya berhasil menciptakan perubahan sosial yang mengarah pada tujuan pembangunan abad millennium atau MDGs.

\section{KESIMPULAN}

Peran wanita dalam penelitian ini berada pada analisa dwiperan dimana pemimpin Posdaya Plamboyan yang berlatarbelakang wanita menempatkan peranan domestik dengan peranan publik berada pada posisi sama penting.Dalam melakukan aktivitas kepemimpinannya, pemimpin Posdaya Plamboyan cenderung lebih bergaya transformasional dimana pemimpin tersebut lebih demokratis dan partisipatif.

Berdasarkan teori struktural-fungsional, kepemimpinan yang dilakukan oleh seorang wanita pada Posdaya Plamboyan terbukti dapat mengarahkan masyarakat Kampung Sukamaju Timur RW 11 Desa Kayuambon Lembang menuju perubahan yang bersifat konstruktif. Dengan beragam upaya penyesuaian atau adaptasi yang dilakukan, pola perilaku masyarakat dapat berubah sesuai dengan tujuan pemberdayaan yang ada di Posdaya Plamboyan. Keluarga yang dijadikan ujung tombak sasaran pemberdayaan untuk memperbaiki pendidikan, ekonomi, dan kesehatan masyarakat dengan pilar keswadayaan dan kemandirian sebagai semangat kerjanya berhasil menciptakan perubahan sosial yang mengarah pada tujuan pembangunan abad millennium atau MDGs.

\section{REFERENSI}

Ahdiah, I. (2013). Peran-Peran Perempuan dalam Masyarakat. Jurnal Academica, vol 5, No 2, hlm. 1085-1092. 
Denim, S. (2012). Motivasi Kepemimpinan \& Efektifitas Kelompok. Jakarta: Rineka Cipta.

Febrina, dkk. (2016). Sosial-Ekonomi dalam Rumah Tangga. Artikel Publikasi, 1-18. 